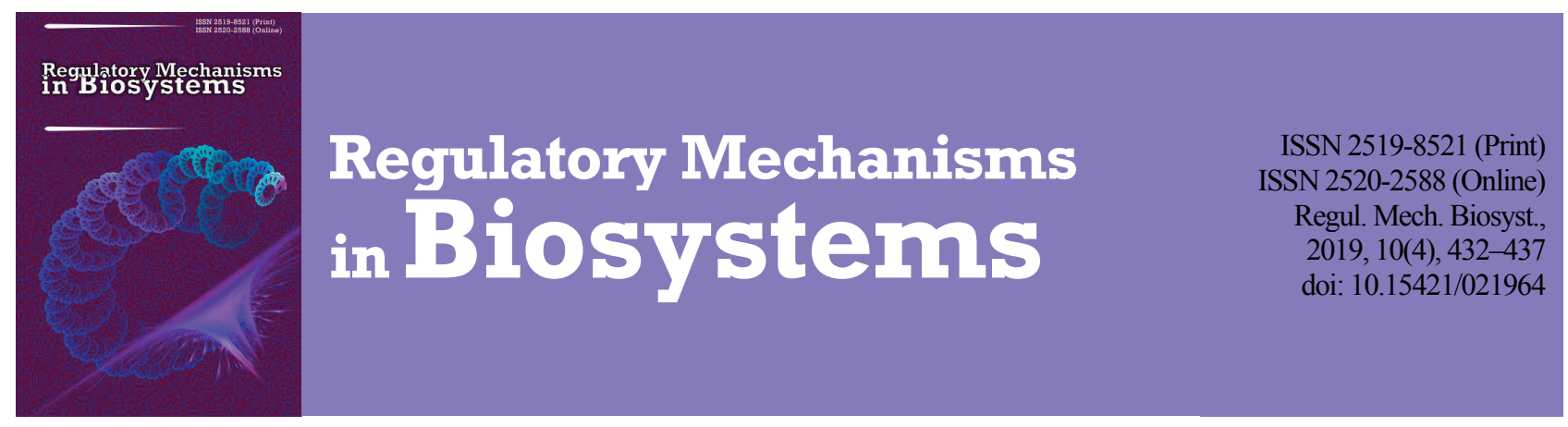

\title{
Fruits of new selection forms and varieties of snowball tree for manufacture of products of therapeutic and prophylactic purpose
}

\author{
T. Z. Moskalets*, V. V. Moskalets*, A. H. Vovkohon**, O. V. Knyazyuk*** \\ *Institute of Horticulture, National Academy of Agrarian Science of Ukraine, Kyiv, Ukraine \\ **Bila Tserkva National Agrarian University, Bila Tserkva, Ukraine \\ ***Mykhailo Kotsiubynskyi Vinnytsia State Pedagogical University, Vinnytsia, Ukraine
}

\begin{abstract}
Article info
Received 16.09.2019

Received in revised form 21.10.2019

Accepted 22.10.2019

Institute of Horticulture,

National Academy of Agra-

rian Science of Ukraine,

Sadova st., 23,

Kyiv, 03027, Ukraine.

Tel.: +38-044-526-65-48.

E-mail: shunyas-

cience@ukr.net

Bila Tserkva National Agrarian University,

Soborna Ploshcha, 8/1,

Bila Tserkva, 09100, Ukraine.

Tel.: +38-045-635-12-88.

E-mail:alinavovk1@ukr.net

Mykhailo Kotsiubynskyi

Vinnytsia State Pedagogical

University, Ostrozkoho st., 32

Vinnytsia, 21100, Ukraine.

Tel.: +38-043-226-52-20.

Moskalets, T. Z., Moskalets, V. V., Vovkohon, A. H., \& Knyazyuk, O. V. (2019). Fruits of new selection forms and varieties of snowball tree for manufacture of products of therapeutic and prophylactic purpose. Regulatory Mechanisms in Biosystems, 10(4), 432-437. doi:10.15421/021964

The paper presents the results of the comparative assessment of varieties and selected breeding forms of the snowball tree $(\mathrm{Vi}$ burnum opulus L., Adoxaceae). The article presents the biochemical composition, marketable and taste qualities of fruits of varieties and elite forms of the snowball tree of regular selection of the Institute of Horticulture of the NAAS and its network, grown under conditions of the Central part of the Forest-Steppe of Ukraine. We selected the sources of specific economic and valuable features: large-fruits (weight of the fruit of 1.24-1.80 g, weight of bunch of 109-126 g - Velykoplidna, Ania, Uliana, EF-3-10-2010), high taste qualities - degustation evaluation of 8.8-9.0 points and chemical composition of fruits (EF-5-12-2012, EF-3-10-2010, Bagriana, Koralova). The study revealed that the fruits of some selection samples are promising raw materials for production of food products and ingredients of functional purpose, including syrups, mors, juices (varieties Koralova, Bahriana, Ania, Uliana, EF-3-10-2010, EF-5-12-2012, EF-7-31-12 with sugar-acid index of 4.86-7.63 and juiciness of the fruit of 4.86-7.63\%); jelly, marmalade (Bahriana, Ania, Koralova, EF-3-10-2010, which have increased content of pectic substances - $9.1-13.0 \mathrm{mg} / \mathrm{kg}$ and P-active compounds - 740-950 mg\%); powdered food additives (Koralova, EF-3-10-2010, EF-5-12-2012, EF-7-31-12); manufacturing pharmaceuticals (EF-2-56-13). Consumption of these products reduces the risk of diet-related diseases, preventing deficiency and replenishing nutrients in the human body, thus preserving and improving health due to the presence of physiologically functional ingredients in their composition. The modern food industry is paying more attention to healthy food with a balanced composition of nutrients, including functional products. Today the snowball tree is a niche plant both in Ukraine and in the world. According to national scientists and market analysts, today some important factors of the cultivation expediency of snowball tree fruits can be distinguished. The weather and climate and soil conditions in Ukraine are quite favourable for cultivation of this plant. The creation of raw material zones would allow the population to be provided with functional products in sufficient quantity, and, if necessary, allow this plant to be cultivated for export.
\end{abstract}

E-mail:

shevchukoksana8@gmail.com

Keywords: Viburnum opulus L.; breeding; biometric parameters; organoleptic and technological characteristics of fruits; biochemical composition; functional products.

\section{Introduction}

Current trends in the formation of a healthy diet dictate the need to create new products with increased biological and physiological value (Sizaya et al., 2017; Kozlowska et al., 2018; Zakłos-Szyda et al., 2019). In order to preserve the environment more and more attention is being paid to organic production of agricultural products (Živělová \& Crhová, 2013; Boyko et al., 2016; Bryła, 2016; Boyko \& Brygadyrenko, 2017; Tkachenko et al., 2019). This is the guarantor of obtaining regulatory safe raw materials and food, the recipes of which include no synthetic preservatives, fragrances, dyes (Skrovankova et al., 2015; Saltan et al., 2016; Ersoy et al., 2017). An alternative source of many components of nutrition are fruit plants, in particular, rowan Sorbus aucuparia L., aronia Aronia melanocarpa (Michx.) Elliott, amelanchier Amelanchier canadensis (L.) Medik., sea buckthorn Hippophae rhamnoides L., quince Cydonia oblonga Mill., snowball tree Viburnum opulus L., dogwood Cornus mas L. and others (Golubieva et al., 2016; Sizaya et al., 2017; Moskalets et al., 2019). Their raw materials are a source of vitamins, minerals, dietary fiber and other vital nutrients, necessary for normal metabolic processes in the human body (Skrovankova et al., 2015; Jurikova et al., 2019). A promising pro-

duct of recycling is the fruits of snowball tree (Viburnum opulus L.), which contain monosaccharides, pectic substances, organic acids, vitamins (C, P, E, K), carotenoids, bioflavonoids, glycosides, antioxidants, bioavailable complexes of macro- and microelements, etc. (Kraujalyte et al., 2013; Golubieva et al., 2016; Ceylan et al., 2018; Frantsishko et al., 2019). Modern technologies using fruit and berry raw materials make it possible to produce food with sufficiently varied and useful chemical composition (Česonienè et al., 2010; Erdem et al., 2016; Ersoy et al., 2017; Ceylan et al., 2018; Cory et al., 2018; Ecevit-Genç \& Yildirim, 2018). Therefore providing the processing, food and pharmaceutical industries with high vitamin raw materials, obtained as a result of creating varieties of fruits with high quality and taste properties, is of high practical and breeding importance (Karaçelik et al., 2015; Goszcz et al., 2017; Konarska \& Domaciuk, 2018; Kozlowska et al., 2018).

Recently, both abroad and in Ukraine the number of works on the use of natural plant resources as food has been increasing (Moskalets \& Rybalchenko, 2016; Sizaya et al., 2017). In this regard, special attention is paid to a comprehensive study and further use in economic activity of nutrionally valuable fruit and berry plants. The snowball tree ( $V$. opulus) is not an exception (Česoniene et al., 2010; Kucharska et al., 2015; Popova, 
2017). In addition, it performs the most important soil protection functions, and is broadly used as an agro-forest ameliorant (Shchetilina et al., 2016).

Fruits of the snowball tree can be maintained well in long term storage, in which their biologically active substances are preserved, which is important in practical terms for their processing. However, unfortunately, snowball tree fruits are underused in the production of products at catering establishments, despite their high biological value (Tsuchiya, 2015; Saltan et al., 2016; Sariözkan et al., 2017). Broader and more rational use of snowball tree fruits is possible only after complex assessment of their chemical composition. Today, fruits of the snowball tree are of great interest as raw materials in the manufacture of products with target function action. The use of snowball tree fruits as a highly efficient raw material for processing and a wide range of uses in nutrition, including as food additives is described in works by the domestic and foreign scientists: Kucharska et al. (2015), Golubieva et al. (2016), Shchetilina (2016), Jurikova et al. (2017), Popova (2017), Sizaya et al. (2017), Polka et al. (2019).

Specialists of the Ivano-Frankivsk Association Carpatfoodindustry have developed receipes and technologies for various snowball tree fruit-based products and semi-finished products of therapeutic and prophylactic purpose. On the basis on the snowball tree, the scientists of the Ivano-Frankivsk National Medical University are developing new high-performance drugs. Scientists of the Academician Z. O. Maniv Department of Economic Theory of the King Danylo Halytsky IvanoFrankivsk University together with specialists from the food industry and forestry are investigating the prospects for the use of wild fruits, berries and mushrooms in the Prykarpattia region in the production of medical-prophylactic products (Sizaya et al., 2017; Moskalets et al., 2019; Polka et al., 2019). The possibility and perspective of using squeezes, powders from the snowball tree in the production of desserts, bakery products, kissels, spices and colourings have been shown repeatedly (Shchetilina et al., 2016; Goszcz et al., 2017; Konarska \& Domaciuk, 2018).

The "State Register of Plant Varieties Suitable for Dissemination in Ukraine" as of August 2019 included 7 varieties of $V$. opulus, which opens up opportunities of its industrial cultivation and provision as a raw material to the processing and pharmaceutical industries. In this regard, search, selection and creation of new high-performance varieties of snowball tree with high consumer and biochemical properties is relevant.

Therefore the objective of our research was the survey and development of large-fruited and highly productive varieties of snowball tree with high quality indicators of fruits, suitable for industrial plantations for obtaining valuable raw materials for production of products of functional purpose, including powdered food additives, syrups, marmaledes and drugs. Study goals were: ball tree;

- to develop large-fruited and high-performance varieties of snow-

to determine the organoleptic, biochemical, technological indicators and nutritional properties of its fruits;

- to ascertain the suitability of raw fruit for the production of functional products, including powdered food additives, syrups, marmalades and drugs. The objects of our study were plants of selected forms and varieties of the snowball tree, fruits and products of their processing.

\section{Materials and methods}

The studies were conducted in 2017-2019 in the Institute of Horticulture of the National Academy of Agrarian Sciences of Ukraine (the soil was dark grey podzolic, the content of easily hydrolysed nitrogen equaled 89 , mobile phosphorus -153 , exchangeable potassium $-111 \mathrm{mg} / \mathrm{kg}$ ). We studied the collections and selected elite forms of snowball tree. As a standard (st) we took the regional variety of Ukrainian breeding Velykoplidna. Care of the experimental plants was carried out using common agricultural measures. Protection measures against pests and pathogens were not taken.

Degustation evaluation of fruits was performed by organoleptic properties (visual appearance, consistency, taste and aroma of berries) (Syedova, 1995; Syedova \& Ogoltceva, 1999) according to a 9-point scale: 9 fruits above excellent quality, 8 - fruits of excellent quality, 7 - fruit above good quality, 6 - good quality fruits, 5 - fruits above satisfactory quality, 4 - fruits of satisfactory quality, 3 - fruits of poor quality, 2 - fruits of very poor quality, 1 - the fruits are completely unsuitable for consumption. Phenological observations on plant growth and development, as well as biometric parameters (weight of the fruit, bunches, quantity of fruits in a bunch, etc.) were performed and determined by methods of the State Commission of Ukraine for Testing and Protection of Plant Varieties. The fruits were harvested by hand, productivity was determined by weighing.

The solids' content was determined by weighing according to SSU 7804:2015 (2015); content of total sugars - photocolorimetric method on the photocalorimeter KFK-3-01 - to SSU ISO 4954:2008 (2009); organic acids - by titration with $0.1 \mathrm{n} \mathrm{NaOH}$ with recalculation for malic acid - to SSU 4957:2008 (2009); vitamin C - titrimetric method by restoration of Tillman's reagent, by extraction from weighed amount fruits using acid solution followed by filtration of the resulting substrate according to SSU 7803:2015 (2015); content of $\beta$-carotene - by paper chromatography followed by photoelectrocolorimetry to SSU 4305:2004 (2005); content of polyphenolic compounds - using the Folin-Denis reagent spectrophotometric method on the spectrophotometer Spekol 1500 at a wavelength of $270 \mathrm{~nm}$ with a photometric accuracy of 0.004 to SSU ISO 4373:2005 (2006); content of P-active compounds spectrophotometrically, antioxidant activity - were determined using Blisar A analyzer of antioxidant activity recalculated into gallic acid (Kucherenko, 2001); pectic substances - spectrophotometrically to SSU ISO 8069:2015 (2017). Biochemical analyses were performed in 4 replication in each variant of the experiment.

The differences between the values in the control and experimental groups were determined using ANOVA, where the differences were considered significant at $\mathrm{P}<0.05$ (with Bonferroni correction). The results were defined as means \pm standard error $(x \pm S E)$. The standard error of the mean (SD) was calculated using analysis of variance taking into account the Bessel's correction, because a small sample was taken $(\mathrm{n}<50)$.

\section{Results}

The results of our studies showed that the greatest weight of the fruits belongs to the elite selected forms: Uliana, Ania (weight of the fruit equaled 1.71-1.80 g) with a sweet taste without bitterness and organoleptic evaluation at 8.3-8.7 points, with the weight of bunches of $22.5,23.5 \mathrm{~g}$ and average quantity of fruits in a bunch $-59-67$, respectively $(\mathrm{P}<0.05)$. At the same time the average weight of the fruit of the control variety Velykoplidna was $1.24 \mathrm{~g}$, weight of a bunch $-115 \mathrm{~g}$ and average quantity of fruits in a bunch of 79. It should be noted that over the years of the study the average weight of the fruit in the varieties Bagriana, Koralova, Ukrainochka, Rubinova was within 1.02-1.20 g with average weight of the bunch of 76-103 $\mathrm{g}$ and quantity of fruits in a bunch 55-73. The smallest mass of fruits belonged to the following forms: EF-7-31-12, EF-2-56-13, EF-5-12-2012 (0.65-0.70) and variety Koralova (0.92), however, with significant productive potential with weight of bunches equaling 63-103 g and quantity of fruits in a bunch of $29-61(\mathrm{P}<0.05)$.

Degustation evaluation (8.8-9.0 points) of selection forms EF-512-2012 and EF-7-31-12 with strongly sweet fruits with insignificant bitterness and bright colour, as well as of sweet forms without bitterness (Ania, Uliana, EF-3-10-2010) with degustation value of 8.3-8.9 points, was higher than for the varieties Bagriana, Koralova and higher than the control variety Velykoplidna sweet without bitterness according to the tasting evaluation, which is at the level of (8.1 points). Differences in degustation value of fruit of snowball tree are important in developing and forming features of their processing products. Fruits of the snowball tree are material for diverse use by the content of the separate components: juice, puree, seeds, peel. Technological properties of snowball tree fruits play an important role during their processing: determine the output of the product, waste content, and quality of processing products. The consistency of the fruits from the studied varieties of snowball tree is dense, juicy, with easily separated seeds.

The juiciness of the fruit of almost all the samples did not exceed 70 $75 \%$. The lowest juice output $(60-64 \%)$ was obtained from samples of snowball trees EF-2-56-13, EF-3-10-2010, EF-7-31-12, Ukrainochka, Rubinova. Waste (seeds and peel) is from $8-15 \%$. According to these characteristics, the fruits of the varieties Ania, Uliana were superior to the 
control: juice output was higher by $3-15 \%$, the pulp $-5-17 \%$. According to the high juiciness indicator $(76-81 \%)$ and due to the pleasant sweet taste with a slight bitterness, the use of the fruits of the abovementioned varieties in the production of fruit juices is quite promising. All the investigated fruits of snowball tree were characterized by low content of organic acids $-1.34-2.29 \%(\mathrm{P}<0.05)$. The presence of organic acids in the fruits of snowball tree not only increases their resistance to pathogens and pests, but also enlarges the technological capabilities of their processing.

The most acid-containing fruits are those of snowball trees EF-3-102010, EF-2-56-13 (1.94-2.29\%), varieties Uliana, Ania (1.89-2.26\%), compared with the control - variety Velykoplidna, $1.79 \%$. Low-acid fruits were characteristic of the varieties: Rubinova, Koralova, Ukrainochka, EF-5-12-2012 (1.12-1.52\%). The highest content of sugars was observed in the fruits of the varieties Ukrainochka, Rubinova, Bahriana, Koralova, EF-7-31-12 (9.1-12.6\%), which is significantly higher than the content of total sugars in the fruits of the control variety Velykoplidna (8.7\%). The sugar-acid index of the studied fruits ranged from 2.97-8.29 $(\mathrm{P}<0.05)$, and in varieties Velykoplidna, Ania, Uliana, EF-3-10-2010, EF 2-56-13 was less than 5 . Statistically reliable differences were determined by biochemical indicators of snowball tree fruits (Table 2). Therefore, the maximum amount of solids was found in the fruits of EF-3-10-2010, EF-5-122012, EF-7-31-12, EF-2-56-13 Koralova (21.4-24.7\%), and minimal in fruits of Uliana and Velykoplidna varieties equaling 14.3-16.8\%. A quite high content of polyphenols and P-active substances $(618-950 \mathrm{mg} \%$ ) was observed in the fruits $(6,020-11,053 \mathrm{mg} / \mathrm{kg})$, which indicates the possibility of use of fruits as raw materials for the production of therapeutic and prophylactic products. Our results showed that the fruits of all the samples contained no less than $40 \mathrm{mg} / 100 \mathrm{~g}$ of ascorbic acid $(\mathrm{P}<0.05)$. As the results of our research show, the fruits of $V$. opulus are rich in pectin substances (from $4.6-13.0 \mathrm{mg} / \mathrm{kg}$ ). This amount of pectin substances in its fruits is of interest due to their preventive properties. Carotene content in the studied snowball tree fruits was insignificant, equaling $2.1-5.3 \mathrm{mg} / \mathrm{kg}$
$(\mathrm{P}<0.05)$. Among the tested varieties particular attention is drawn to the form EF-2-56-13 with a low sugar-acid index (2.97), high content of titrated acids $(2.29 \%)$ but with a very bitter taste of the fruit, and therefore high in glycoside viburnin.

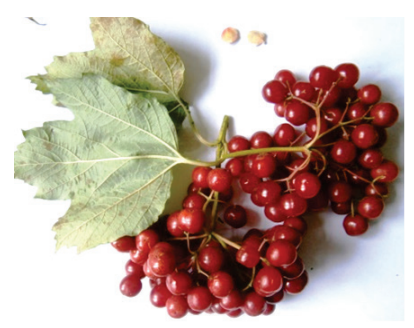

A

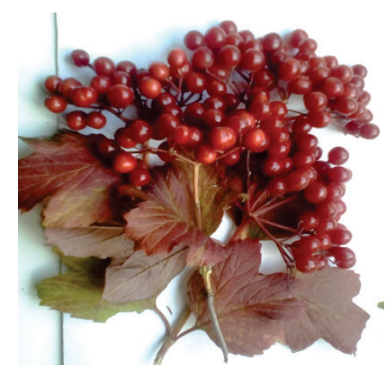

C

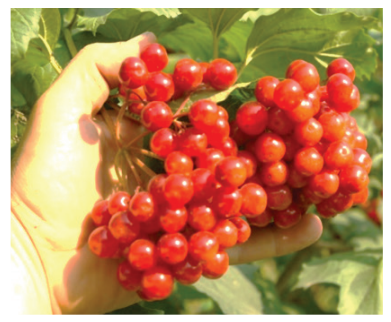

B

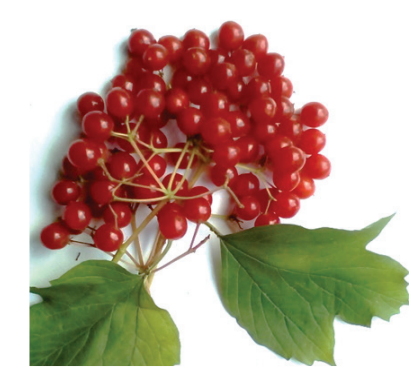

Fig. 1. Fruits of varieties and elite forms of snowball tree selection of Institute of Horticulture NAAS: $A$ - variety 'Uliana', $B$ - variety 'Ania', $C$ - elite form 5-12-2012, $D$ - elite form 2-56-13 (the authors: V. Frantsishko, T. Moskalets, V. Moskalets, I. Grynyk, I. Matlay; Frantsishko et al., 2019)

Table 1

Biometric, organoleptic and technological characteristics of fruits of elite forms and varieties of snowball tree, the average 2017-2018 ( $n=4)$

\begin{tabular}{|c|c|c|c|c|c|c|c|c|c|}
\hline $\begin{array}{l}\text { Variety, } \\
\text { form }\end{array}$ & $\begin{array}{l}\text { Weight of the } \\
\text { fruit, } g\end{array}$ & $\begin{array}{l}\text { Weight of } \\
\text { bunch, } g\end{array}$ & $\begin{array}{l}\text { Quantity of fruits } \\
\text { in a bunch, pcs. }\end{array}$ & $\begin{array}{l}\text { Titration organic } \\
\text { acids, } \%\end{array}$ & $\begin{array}{c}\text { Total sugars, } \\
\%\end{array}$ & $\begin{array}{l}\text { Sugar-acid } \\
\text { index }\end{array}$ & $\begin{array}{l}\text { Juiciness of the } \\
\text { fruit, } \%\end{array}$ & Taste & $\begin{array}{l}\text { Tasting eva- } \\
\text { luation, point }\end{array}$ \\
\hline$\overline{\text { Velykoplidna (st) }}$ & $1.24 \pm 0.07$ & $115 \pm 1.20$ & $79 \pm 1.60$ & $1.79 \pm 0.11$ & $8.7 \pm 0.87$ & 4.86 & $71 \pm 2.01$ & & 8.10 \\
\hline Bahriana & $1.20 \pm 0.08$ & $94 \pm 2.11$ & $55 \pm 2.84$ & $1.63 \pm 0.05$ & $9.5 \pm 0.22 *$ & $5.83^{*}$ & $66 \pm 1.94$ & sweet with bitterness & $8.80^{*}$ \\
\hline Koralova & $0.92 \pm 0.08$ & $103 \pm 0.90$ & $61 \pm 3.90$ & $1.35 \pm 0.10$ & $9.1 \pm 0.35^{*}$ & $6.74 *$ & $65 \pm 2.04$ & & $8.90^{*}$ \\
\hline Rubinova & $1.19 \pm 0.05$ & $76 \pm 2.02$ & $68 \pm 2.51$ & $1.34 \pm 0.09$ & $10.0 \pm 0.41^{*}$ & $7.46^{*}$ & $63 \pm 0.86$ & sweet with & $8.40 *$ \\
\hline Ukrainochka & $1.15 \pm 0.06$ & $88 \pm 1.50$ & $73 \pm 1.90$ & $1.52 \pm 0.14$ & $11.6 \pm 0.30 *$ & $7.63^{*}$ & $61 \pm 1.52$ & iticant bitterness & 8.10 \\
\hline Ania & $1.80 \pm 0.09 *$ & $126 \pm 1.90^{*}$ & $59 \pm 2.43$ & $2.07 \pm 0.06^{*}$ & $8.5 \pm 0.19$ & 4.11 & $81 \pm 2.65^{*}$ & & $8.30 *$ \\
\hline Uliana & $1.71 \pm 0.07 *$ & $109 \pm 1.20$ & $67 \pm 1.50$ & $1.89 \pm 0.08^{*}$ & $8.0 \pm 0.20$ & 4.23 & $76 \pm 1.43^{*}$ & sweet without & $8.70 *$ \\
\hline EF-3-10-2010 & $1.01 \pm 0.05$ & $81 \pm 0.84$ & $49 \pm 2.62$ & $1.94 \pm 0.12 *$ & $8.8 \pm 0.15$ & 4.54 & $62 \pm 2.58$ & & $8.90 *$ \\
\hline EF-5-12-2012 & $0.70 \pm 0.08$ & $76 \pm 1.40$ & $29 \pm 1.83$ & $1.52 \pm 0.07$ & $12.6 \pm 0.22 *$ & $8.29 *$ & $65 \pm 1.73$ & strongly sweet with & $9.00 *$ \\
\hline EF-7-31-12 & $0,65 \pm 0.06$ & $63 \pm 1.25$ & $37 \pm 1.71$ & $1.74 \pm 0.08$ & $12.5 \pm 0.14^{*}$ & $7.18^{*}$ & $64 \pm 1.86$ & insignificant bitterness & $8.80^{*}$ \\
\hline EF-2-56-13 & $0.69 \pm 0.05$ & $78 \pm 0.62$ & $44 \pm 1.25$ & $2.29 \pm 0.09^{*}$ & $6.8 \pm 0.18$ & 2.97 & $60 \pm 0.95$ & $\begin{array}{l}\text { acidic with strongly } \\
\text { pronounced bitterness }\end{array}$ & 5.00 \\
\hline SE & 0.42 & 19.41 & 13.20 & 0.29 & 1.91 & 1.76 & 6.62 & - & 1.13 \\
\hline $\mathrm{x}$ & 0.98 & 92.00 & 56.00 & 1.73 & 9.60 & 5.80 & 67.00 & - & 8.30 \\
\hline
\end{tabular}

Note: $*-\mathrm{P}<0.05$ compared to the control (standard); SE - standard error of the mean; taste evaluation of fruits performed according to organoleptic parameters on a set of indicators taste and aroma of berries.

Table 2

Biochemical composition of fruits elite forms and varieties of snowball tree, the average 2017-2018 $(n=4)$

\begin{tabular}{|c|c|c|c|c|c|c|c|}
\hline $\begin{array}{l}\text { Variety, } \\
\text { form }\end{array}$ & $\begin{array}{c}\text { Solids } \\
\text { content, \% }\end{array}$ & $\begin{array}{c}\text { Polyphenolic } \\
\text { compounds, } \mathrm{mg} / \mathrm{kg}\end{array}$ & $\begin{array}{c}\text { Pectic substances, } \\
\mathrm{mg} / \mathrm{kg}\end{array}$ & $\begin{array}{l}\text { Vitamin C, } \\
\mathrm{mg} / \mathrm{kg}\end{array}$ & $\begin{array}{c}\beta \text { - carotene, } \\
\mathrm{mg} / \mathrm{kg}\end{array}$ & $\begin{array}{c}\text { P-active } \\
\text { compounds, } \mathrm{mg} \%\end{array}$ & $\begin{array}{c}\text { Antioxidant } \\
\text { activity, } \mathrm{mg} \%\end{array}$ \\
\hline Velykoplidna $(s t)$ & $16.8 \pm 0.4$ & $6204 \pm 193.7$ & $9.1 \pm 1.0$ & $510 \pm 22.2$ & $4.2 \pm 0.2$ & $685 \pm 21.2$ & $392 \pm 40.9$ \\
\hline Koralova & $22.0 \pm 0.3^{*}$ & $7601 \pm 217.4^{*}$ & $13.0 \pm 1.4^{*}$ & $702 \pm 31.0^{*}$ & $5.1 \pm 0.1^{*}$ & $860 \pm 27.5^{*}$ & $531 \pm 13.2 *$ \\
\hline Rubinova & $18.7 \pm 0.2^{*}$ & $5492 \pm 135.0$ & $8.7 \pm 1.2$ & $431 \pm 22.4$ & $4.0 \pm 0.2$ & $720 \pm 18.2$ & $508 \pm 20.5^{*}$ \\
\hline Bahriana & $21.5 \pm 0.3^{*}$ & $6270 \pm 212.3$ & $9.2 \pm 0.5$ & $752 \pm 31.0^{*}$ & $3.3 \pm 0.1$ & $950 \pm 43.5^{*}$ & $519 \pm 19.3 *$ \\
\hline Ukrainochka & $21.4 \pm 0.8^{*}$ & $7403 \pm 195.0^{*}$ & $8.4 \pm 0.8$ & $720 \pm 20.9$ & $2.9 \pm 0.2$ & $830 \pm 36.5^{*}$ & $387 \pm 21.0$ \\
\hline Ania & $19.9 \pm 0.4^{*}$ & $6578 \pm 160.8$ & $9.9 \pm 0.5$ & $456 \pm 31.0$ & $3.7 \pm 0.6$ & $740 \pm 29.2^{*}$ & $512 \pm 33.6^{*}$ \\
\hline Uliana & $14.3 \pm 0.8$ & $6020 \pm 143.4$ & $6.8 \pm 0.6$ & $483 \pm 11.7$ & $2.1 \pm 0.4$ & $715 \pm 27.1$ & $480 \pm 25.3^{*}$ \\
\hline EF 3-10-2010 & $24.7 \pm 0.4^{*}$ & $10828 \pm 120.8^{*}$ & $9.1 \pm 0.7$ & $682 \pm 20.8^{*}$ & $5.3 \pm 0.5^{*}$ & $836 \pm 32.8^{*}$ & $540 \pm 15.5^{*}$ \\
\hline EF 5-12-2012 & $22.1 \pm 0.2 *$ & $10490 \pm 153.5^{*}$ & $4.6 \pm 1.0$ & $511 \pm 31.4$ & $5.0 \pm 0.3^{*}$ & $908 \pm 58.6^{*}$ & $516 \pm 29.8^{*}$ \\
\hline EF-7-31-12 & $23.2 \pm 0.1^{*}$ & $11053 \pm 165.2^{*}$ & $5.7 \pm 1.6$ & $545 \pm 22.3$ & $2.7 \pm 0.6$ & $720 \pm 53.1$ & $503 \pm 31.2 *$ \\
\hline EF-2-56-13 & $22.7 \pm 0.3^{*}$ & $8006 \pm 96.7^{*}$ & $8.3 \pm 0.7$ & $623 \pm 21.8^{*}$ & $3.5 \pm 0.3$ & $618 \pm 25.7$ & $445 \pm 20.5$ \\
\hline SE & 3.2 & 204.9 & 4.6 & 111.6 & 1.3 & 103.0 & 53.0 \\
\hline $\mathrm{x}$ & 20.7 & 780 & 8.4 & 582.0 & 4.2 & 780.0 & 485.0 \\
\hline
\end{tabular}

Note: $*-\mathrm{P}<0.05$ compared to the control (standard); $\mathrm{SE}$ - standard error of the mean. 
The results of our research on determining the antioxidant activity of the investigated snowball tree fruits showed a sufficiently high level. On average, this indicator, depending on the variety, varies from 332 $526 \mathrm{mg} \%$. The highest value of antioxidant activity was exhibited by the fruits of the EF 3-10-2010, Koralova, Bahriana (519-540 mg\%) varieties, somewhat inferior to the fruits of the varieties Ukrainochka, Velykoplidna (387-392 mg\%). Research results of chemical composition of snowball tree fruits showed that due to their content of nutrients and bioactive substances they are a promising raw material for the production of functional foods.

According to the results of the comprehensive evaluation of the varieties and elite forms of fruits of $V$. opulus for food production: for the production of syrups, mors, juices from snowball tree fruits, the following varieties are recommended: Koralova, Bahriana, Ania, Uliana, EF-3-10-2010, EF-5-12-2012, EF-7-31-12, having high organoleptic, technological characteristics and high content of anthocyanins, since colour depends on it, product yield and nutritional value; for the production of sauces we recommend fruit of the varieties Velykoplidna, Ania, Uliana, EF-3-10-2010, EF-2-56-13, which have a high content of organic acids,which means that the number of acidifiers added to the product can be reduced or that they need not be added at all; fruits of the varieties Koralova, Bahriana, Ania, EF-3-10-2010 are recommended for production of gelling and candy products (jellies, candy bars, chocolates) due to the high solids content and natural pectin, to obtain powders and teas, fruits and leaves of all the studied varieties of $V$. opulus are recommended, which are also sources of antioxidants, flavonoids and other biologically active substances; in the manufacture of pharmaceuticals of natural origin (cardiovascular and antispasmodic action) fruits with high glycoside content, particularly those of elite form EF-2-56-13, are promising raw materials.

\section{Discussion}

In the Institute of Horticulture of the NAAS and its network, work on creating collections and separate selective breeds of not commonly used forms, in particular snowball tree, has been going on for a long time. The most important qualitative indicator for any plant is weight of the fruit. Currently 7 varieties of snowball tree are included in the State Register of Plant Varieties Suitable for Dissemination in Ukraine (August 2019), though, results of analytical and synthetic breeding and the conducted biometric and biochemical studies showed that varieties Uliana, Ania and EF-3-10-2010 are promising new high-yielding elite forms which are at the level not inferior to the control (standard) by elements of productivity.

Our studies have shown clear differences in varieties and elite forms in the biochemical composition of fruits, their taste properties, which in turn encourages their further use for particular nutritional or pharmaceutical purposes. This is very important because the hallmark of modern society is healthy food, the leading role in which belongs to consumption of food rich in vitamins, macro and microelements composition. Such requirements are met by leaves, fruits and seeds of the snowball tree (Karaçelik et al., 2015; Goszcz et al., 2017; Konarska \& Domaciuk, 2018; Kozlowska et al., 2018). Studying and conducting comparative assessment of differences in degustation evaluation of fruits of the snowball tree are important for developing features of its processing products. According to the literature, Maksimenko et al. (2014), Zhbanova \& Maslennikov (2015), organic acids in ripe fruits of snowball tree are represented mainly by malic, citric, caprylic, formic, valeric, isovaleric, chlorogenic acids, and also traces of quinic, caffeic and acetic acids were detected. Savieliev et al. (2010), Golubieva et al. (2016), Zhidekhina et al. (2016) reported that green fruits (unlike ripe fruits) are rich in quinic and caffeic acids, the content of which significantly reduces during ripening. Ersoy et al. (2017), Goszcz et al. (2017), Cory et al. (2018), Kizilay (2019) found that the fruits of the snowball tree contain triterpene compounds: $\alpha$ - and $\beta$-amyrin, alanolic and hedrogenic acids and their acetyl derivatives, ursolic acid, as well as steroids represented by phytosterol. Česonienè et al. (2010), Shchetilina et al. (2016) studied a broad range of biologically active substances, including antioxidants, providing new opportunities of using raw materials from the snowball tree in production of pharmaceuticals. According to the literature data Konarska \& Domaciuk (2018), sugars are the main source of energy necessary for different physiological processes in the cell. They determine nutritional characteristics of both fresh fruits of the snowball tree and products of their processing. Content and composition of sugars in fruits of $V$. opulus is represented by the total and invert sugars, as well as glucose, fructose and sucrose. The conducted studies revealed differences between the varieties of snowball tree in the content of total sugars. Studies by Shchetilina et al. (2016), Ersoy et al. (2017), Zakłos-Szyda et al. (2019) determined that polyphenolic compounds of the fruit of the snowball tree are mostly represented by leucoanthocyanins, flavonols, catechins, anthocyanins, chlorogenic acids.

Numerous studies, in particular Česonienè et al. (2010), Maksimenko et al. (2014), Zhbanova \& Maslennikov (2015), Jurikova et al. (2019), demonstrated that pectins (including soluble pectin and protopectin) are stabilizers of ascorbic acid and a good binder of heavy metals, menthol and other toxic substances, contributing to elimination of toxins, cholesterol and radioactive cobalt and strontium. Savieliev et al. (2010), Kucharska et al., (2015), Jurikova et al. (2019) proved that a particularly important role of pectins is the prevention of many types of cancers. Pectin solutions have been shown to have antibacterial properties (Skrovankova et al., 2015; Ceylan et al., 2018). Pectic substances are involved in flavouring, and also have the properties of preserving natural colour and aroma of the fruits in jelly (Golubieva et al., 2016; Cory et al., 2018; Polka et al., 2019). Studies by Golubieva et al. (2016), Cory et al. (2018), Polka et al. (2019) revealed possibilities of using pectic substances of the fruits as a gelling component in public catering, in the food industry, etc. In addition, pectins can be used as an alcohol adsorbent (Popova, 2017; Kozlowska et al., 2018; Zakłos-Szyda et al., 2019).

Konarska \& Domaciuk (2018), Jurikova et al. (2019) do not indicate fruits of snowball tree as fruits of high vitamin value. However, in the fruits of all the samples we found not less than $400 \mathrm{mg} / \mathrm{kg}$ of ascorbic acid, indicating a high nutritional value and technological parameters, allowing them to be used for production of functional syrups, juices, desserts, etc. Vitamin $\mathrm{C}$ is a strong antioxidant, but cannot accumulate in the human body, which is why it is important to consume vitamin C-containing foods regularly. Analysis of vitamin composition and daily vitamin requirements showed that the inclusion of snowball tree fruits in the diet can satisfy over $50 \%$ of the body's need for vitamin C and $1-15 \%$ of the body's need for carotene - content in fruits $2.1-$ $5.3 \mathrm{mg} / \mathrm{kg}$ for the daily requirement for humans $4-5 \mathrm{mg} / \mathrm{kg}$.

The taste and aroma of snowball tree fruits are quite specific due to the presence of valeric acid, essential oils and glycosides. Glycoside of vyburnin provides the fruits with a specific smell. This property, on the one hand, according to some authors (Kucharska et al., 2015; ZakłosSzyda et al., 2019) impedes the distribution of the plant in both industry and private sector gardens. However, national breeders are working on developing new varieties of snowball tree of high quality parameters of fruits and low bitterness. One of the important glycosides of snowball tree is iridoid viburnin. Česonienè et al. (2010), Skrovankova et al. (2015), Tsuchiya (2015), Jurikova et al. (2019) demonstrated that in pharmacy on the basis of iridoids of natural origin, preparations of cardiovascular and antispasmodic group can be produced, and the results of recent studies (Stępień, et al., 2010; Kucharska et al., 2015; Skrovankova et al., 2015) have revealed its antitumour activity. Furthermore, (Kraujalyte et al., 2013; Kucharska et al., 2015; Konarska \& Domaciuk, 2018; Jurikova et al., 2019) have confirmed that biologically active substances of $V$. opulus manifest hemostatic, antiseptic, tonic effect on the human body, and also increase the tone of the uterine muscles and prevent the appearance of varicose veins.

Among the tested varieties particular attention is drawn to the elite form EF-2-56-13 with a low sugar-acid index (2.97), high content of titrated acids (2.29\%) but with a very bitter taste of the fruit, and also high content of glycoside viburnin. And this, in turn, is of great research interest, because information about the presence of this glycoside in biomass of other species of plants in the scientific literature is absent. At the same time there are some reports that this iridoid was found not only in the bark but also in the fruits and leaves of $V$. opulus. Due to the unfavourable environmental situation, the risk of developing cardiovascu- 
lar disease, diseases of the nervous system, lungs, and blood increase every year. This is due to the provision and accumulation of free radicals in the human body (Skrovankova et al., 2015; Jurikova et al., 2019). For prevention of this tendency, introduction of antioxidants, substances that protect it from the negative impact of the environment, into the human body is necessary. The results of our research on determining the antioxidant activity of the investigated fruits of the snowball tree revealed them to have a high antioxidant level. The results showed that by the value of total antioxidant activity,which is characterized by a number of nutrients and biologically active substances, the fruits $V$. opulus constitute a valuable raw material for obtaining healthy and functional foods. The functional properties of snowball tree fruits were generally confirmed by the content of antioxidants: vitamin $C, \beta$-carotene, pectin and flavonoids, providing $20-60 \%$ of the human body's daily requirements for them.

The modern food industry is paying more attention to healthy food with a balanced composition of nutrients, including functional products (Česonienè et al., 2010; Maksimenko et al., 2014; Kucharska et al., 2015; Tsuchiya, 2015; Zhbanova \& Maslennikov, 2015). Analysis of the horticulture industry in general demonstrates that today the snowball tree is a niche culture both in Ukraine and around the world. Domestic scientists and market analysts (Popova, 2017; Sizaya et al., 2017; Moskalets et al., 2019), have distinguished some important factors of the expediency of cultivating snowball tree.

Scientist-practitioners (Golubieva et al., 2016; Ersoy et al., 2017; Popova, 2017; Ceylan et al., 2018; Cory et al., 2019) have repeatedly demonstrated that the following products can be made out of raw materials of snowball tree fruits: concentrated juices, frozen fruits, purreed fruit with sugar, nectars, purees, smoothies, compotes, morses, fruitberry preserves, fruit toppings and fillings, ciders, flavours, sublimated fruits, powders, pectin, jams, marmalade, fruit mixes, fruit marinades, jelly candies - important products in the diet of different groups of people, including children and products for dietary nutrition (Jurikova et al., 2019; Moskalets et al., 2019).

Some scientists, in particular Ersoy et al. (2017), Ceylan et al. (2018), Cory et al. (2019) are paying special attention to a separate group of imported pectin-containing goods, dried fruits and berries, fruits distillates, fruits and berry wines. The state statistics does not distinguish processing of fruits as a separate sphere. According to the official data of State Statistics (Moskalets et al., 2019), a general trend towards reduction of the number of processing enterprises in Ukraine and people employed in this sphere is observed. In 2014, 335 enterprises were engaged in the processing and preservation of fruits and vegetables. The programme of development of horticulture spheres for the period to 2025 aims at stabilization and further increase in the production of fruits and berries; saturation of the domestic food market with competitive products and their wide export; increase in production of normatively safe products due to transition from industrial-chemical methods of farming to biological methods, which ultimately opens up even more opportunities for growing and distributing V. opulus.

Domestic and foreign scientists (Shchetilina et al., 2016; Ersoy et al., 2017; Sizaya et al., 2017), despite considerable experience, have underestimated the value of snowball tree fruits for processing. Using its fruits as a food was shown by Golubieva et al. (2016), Popova (2017), Ceylan et al. (2018), Jurikova et al. (2019). Use of $V$. opulus fruits in pharmaceutics is described in the studies by Karaçelik et al. (2015), Tsuchiya (2015), Erdem et al. (2016), Goszcz et al. (2017), Cory et al. (2019), Zakłos-Szyda et al. (2019). To date, the use of its raw materials in other industries is at a low level. Use of this plant in both industrial and ornamental horticulture is described in the works by Česoniene et al. (2010), Ecevit-Genç \& Yildirim (2018). The main factors which limit its distribution are: strong bitterness of fruits and technological difficulties in growing the plants. Some authors (Ersoy et al., 2017; Sizaya et al., 2017) note the lack of high-yielding varieties of snowball tree and the bitter taste of the fruits of wild plants, which holds back the distribution of the plant both in industrial production and in private sector gardens.

However, currently 9 varieties of universal purpose count as national achievements: 5 selections of Mliiv SRS Institute of Horticulture of the National Academy of Agrarian Science (Ukrainochka, Rubinova,
Koralova, Bahriana, Velykoplidna), 2 - selection of M. M. Gryshko National Botanical Garden of the National Academy of Science (Berehyni, Nasoloda), 2 - Institute of Horticulture of the National Academy of Agrarian Science of Ukraine (Ania and Ulian). These are high-yielding varieties (14-20 tha) with high qualitative indicators of fruits and low bitterness, especially the latter two. In recent years, work on creation of plantations of $V$. opulus has begun, particularly, the Deliatyn Forestry (Ivano-Frankivsk Oblast) (Sizaya et al., 2017) with the total yield of 100 tons of fruits of snowball tree/year, Svirzh Forestry (Lviv Oblast, area 0.6 ha), Brody Forestry (Lviv region 0.5 ha) and others (Moskalets et al., 2019). Today, snowball tree fruits are intended for systematic consumption in all age groups in the healthy population. Consumption of these products reduces the risk of diseases related to food, preventing deficiency or replenishing nutrients in the human body, which preserves and improves health due to the presence of physiologically functional ingredients in their composition.

\section{Conclusions}

Thus, the study revealed that the fruits of selective breeding forms and varieties of snowball tree grown in the conditions of the ForestSteppe of Ukraine have high organoleptic and biochemical properties. Content of organic acids, carotene, P-active compounds and antioxidants in snowball tree fruits is characterized by their high consumer properties, giving them more potential use in the food, processing, pharmaceutical industries in the production of healthy and functional foods, medical drugs. In particular, for the production of syrups and morses from snowball tree fruits of the following varieties are recommended: Koralova, Bahriana, EF-3-10-2010, EF-5-12-2012, EF-7-31-12, having high organoleptic (tasting evaluation 8.8-9.0 points), technological characteristics (weight of the fruit equaling $0.65-1.20 \mathrm{~g}$, weight of bunch 81-103 g) and high content of anthocyanins, since colour depends on it, product yield and its nutritional value. For the production of sauces, fruits of the following varieties are recommended: Velykoplidna, Ania, Uliana, EF-3-10-2010, EF-2-56-13, which have a high content of organic acids (1.89-2.29\%), which permits the elimination or reduction in the number of acidifiers added to the product; fruits of the varieties of snowball tree Koralova, Bahriana, Ania, EF-3-10-2010 are recommended for production of jelly, marmalade, candy and lactic acid fermented dairy products (jellies, sweets, cheese desserts, yoghurts, kefir) and powdered food additives due to the high content of solids (19.9-24.7\%) and natural pectin $(9.1-13.0 \mathrm{mg} / \mathrm{kg}$ ), which reduces the quantitative content of pectin added to the product and allows candied mass of required density to be obtained; to obtain powders and teas, fruits and leaves of all the examined varieties of $V$. opulus are recommended, as they are sources of antioxidants, flavonoids and other biologically active substances; in the manufacture of pharmaceuticals of natural origin (cardiovascular and antispasmodic preparations) promising glycoside-containing materials are fruits of the elite form EF-2-56-13.

\section{References}

Boyko, A. A., \& Brygadyrenko, V. V. (2017). Changes in the viability of the eggs of Ascaris suum under the influence of flavourings and source materials approved for use in and on foods. Biosystems Diversity, 25(2), 162-166.

Boyko, O. O., Zazharska, N. M., \& Brygadyrenko, V. V. (2016). The influence of the extent of infestation by helminths upon changes in body weight of sheep in Ukraine. Visnyk of Dnipropetrovsk University. Biology, Ecology, 24(1), 3-7.

Bryła, P. (2016). Organic food consumption in Poland. Motives and Barriers, 105, $737-746$.

Česonienė, L., Daubaras, R., Venclovienė, J., \& Viškelis, P. (2010). Biochemical and agro-biological diversity of Viburnum opulus genotypes. Central European Journal of Biology, 5(6), 864-871.

Ceylan, D., Aksoy, A., Ertekin, T., Yay, A. H., Nisari, M., \& Karatoprak, G. Ş. (2018). The effects of gilaburu (Viburnum opulus) juice on experimentally induced Ehrlich ascites tumor in mice. Journal of Cancer Research and Therapeutics, $14,314-320$.

Cory, H., Passarelli, S., Szeto, J., Tamez, M., \& Mattei, J. (2018). The role of polyphenols in human health and food systems: A mini-review. Frontiers in Nutrition, 5, 87. 
Derzhavniy reiestr sortiv roslyn, prydatnykh dlia poshyrennia v Ukrajiny na 2019 rik [State register of plant varieties suitable for dissemination in Ukraine in 2019]. (2019). State Commission of Ukraine for Testing and Protection of Plant Varieties, Ministry of Agricultural Policy and Food of Ukraine, Kyiv (in Ukrainian).

Ecevit-Genç, G., \& Yildirim, H. N. (2018). Leaf and petiole anatomy of Viburnum opulus L. (Adoxaceae). Journal of Science and Technology, 11(1), 102-106.

Erdem, G., Kesik, V., Honca, T., Özcan, A., Uğuz, S., Akgül, E. Ö., Aykutlug, Ö., Alp, B. F., Korkmazer, N., Saldir, M., \& Bayrak, Z. (2016). Antinephrolithiatic activity of Persea americana (avocado) and Viburnum opulus (guelder rose) against ethylene glycol-induced nephrolithiasis in rats. African Journal of Traditional, Complementary and Alternative Medicines, 13, 110-119.

Ersoy, N., Ercisli, S., \& Gundogdu, M. (2017). Evaluation of European cranberry bush (Viburnum opulus L.) genotypes for agro-morphological, biochemical and bioactive characteristics in Turkey. Folia Horticulturae, 29, 181-188.

Frantsishko, V. S., Moskalets, T. Z., \& Moskalets, V. V. (2019). Dosiahnennia ta kontseptualni napriamy vyroshchuvannia maloposhyrenykh plodovo-yahidnykh kultur ta pererobky yikh syrovyny [Achievements and conceptual directions cultivation of rare fruit crops and processing of their raw materials]. Center for Educational Literature, Kyiv (in Ukrainian).

Golubieva, L. V., Dolmatova, O. I., \& Ivantsova, M. I. (2016). Kislomolochnyi produkt funktsyonalnogo naznachieniia [Fermented milk product functional purpose]. Journal Proceedings of the Voronezh State University of Engineering Technologies, 2, 148-152 (in Russian).

Goszcz, K., Duthie, G. G., Stewart, D., Leslie, S. J., \& Megson, I. L. (2017). Bioactive polyphenols and cardiovascular disease: Chemical antagonists, pharmacological agents or xenobiotics that drive an adaptive response? British Journal of Pharmacology, 174, 1209-1225.

Jurikova, T., Skrovankova, S., Mlcek, J., Balla S., \& Snopek, L. (2019). Bioactive compounds, antioxidant activity, and biological effects of european cranberry (Vaccinium oxycoccos). Molecules, 24(1), 17-21.

Karaçelik, P., Küçük, A. A., Iskefiyeli, M., Aydemir, Z., de Smet, S., Miserez, S., \& Sandra, B. (2015). Antioxidant components of Viburnum opulus L. determined by on-line HPLC-UV-ABTS radical scavenging and LC-UVESI-MS methods. Food Chemistry, 175, 106-114.

Kızılay, F., Ülker, V., Çelik, O., Özdemir, T., Çakmak, Ö., Can, E., \& Nazlı, O. (2019). The evaluation of the effectiveness of Gilaburu (Viburnum opulus L.) extract in the medical expulsive treatment of distal ureteral stones. Turkish Journal of Urology, 1(1), 7-9.

Konarska, A., \& Domaciuk, M. (2018). Differences in the fruit structure and the location and content of bioactive substances in Viburnum opulus and Viburnum lantana fruits. Protoplasma, 255(1), 25-41.

Kozlowska, W., Wagner, C., Moore, E. M., \& Matkowski, A. (2018). Botanical provenance of traditional medicines from Carpathian mountains at the Ukrainian-Polish border. Frontiers in Pharmacology, 9, 295.

Kraujalyte, V., Venskutonis, P., Pukalskas, A., Česonienė, L., \& Daubaras, R. (2013). Antioxidant properties and polyphenolic compositions of fruits from different European cranberry bush (Viburnum opulus L.) genotypes. Food Chemistry, 141, 3695-3702.

Kucharska, A., Szumny, A., Sokół-Łętowska, A., Piórecki, N., \& Klymenko, S. (2015). Iridoids and anthocyanins in cornelian cherry (Cornus mas L.) cultivars. Journal of Food Composition and Analysis, 40, 95-102.

Kucherenko, M. Y. (2001). Suchasni metody biokhimichnykh doslidzhen [Modern methods of biochemical research]. Phitosociocenter, Kyiv (in Ukrainian).
Moskalets, T. Z., \& Rybalchenko, V. K. (2016). Kontseptualna model keruvannia zhyttievym stanom roslynnykh ekomorf za kryteriiamy mekhanizmiv adaptyvnosti [Conceptual model of management the vital state plant ecomorphs by the criteria of adaptation mechanisms]. Visnyk of Dnipropetrovsk University, Biology, Ecology, 4(1), 211-221 (in Ukrainian).

Moskalets, T. Z., Moskalets, V. V., Vovkohon, A. H., Shevchuk, O. A., \& Matviichuk, O. A. (2019). Modern breeding and cultivation of unpopular fruits and berries in Ukraine. Ukrainian Journal of Ecology, 9(3), 204-213.

Polka, D., Podsędek, A., \& Koziołkiewicz, M. (2019). Comparison of chemical composition and antioxidant capacity of fruit, flower and bark of Viburnum opulus. Plant Foods for Human Nutrition, 74(3), 436- 442.

Popova, E. I. (2017). Innovatsyonnaia tekhnologiia fruktovykh snekov dlia funktsyonalnogo pitaniia iz kaliny obyknovennoy [Innovative technology of fruit snacks production from European cranberrybush for functional nutrition]. Journal Michurinsk State Agricultural University, 3, 122-127 (in Russian).

Saltan, G., Süntar, I., Ozbilgin, S., Ilhan, M., Demirel, M., Oz, B., \& Akkol, E. (2016). Viburnum opulus L.: A remedy for the treatment of endometriosis demonstrated by rat model of surgically-induced endometriosis. Journal of Ethnopharmacology, 193, 450-455.

Sarı̈zkan, S., Türk, G., Eken, A., Bayram, L., Baldemir, A., \& Doğan, G. (2017). Gilaburu (Viburnum opulus L.) fruit extract alleviates testis and sperm damages induced by taxane-based chemotherapeutics. Biomed Pharmacother, 95, 1284-1294.

Shchetilina, I. P., Popova, N. N., Kiseleva, E. A., \& Denisova, A. A. (2016). Razrabotka retseptury kisielia funktsyonalnogo naznachieniia s ispolzovaniem mestnogo yagodnogo syria [Formula of functional jelly using local berries]. Vestnik of International Academy of Refrigeration, 2, 38 - 41 (in Russian).

Skrovankova, S., Sumczynski, D., Mlcek, J., Jurikova, T., \& Sochor, J. (2015). Bioactive compounds and antioxidant activity in different types of berries. International Journal of Molecular Sciences, 16, 24673-24706.

Sizaya, O., Savchenko, O., Zhurok, I., \& Dorozhynska, M. (2017). Poroshok z vychavkiv yagid kalyny v tekhnolohii vyrobnytstva pshenychnoho khliba [Powder from the schrot of berries of kalina in the technology of production of wheat bread]. Technical Sciences and Technologies, 4(10), 176-188 (in Ukrainian).

Tkachenko, A., Birta, G., Burgu, Y., Floka, L., \& Kalashnik, O. (2018). Substantiation of the development of formulations for organic cupcakes with an elevated protein content. Eastern-European Journal of Enterprise Technologies, 93, 51-58.

Tkachenko, A., Syrokhman, I., Lozova, T., Ofilenko, N., Goryachova, E., Hmelnitska, Y., \& Shurduk, I. (2019). Research of consumer properties of developed biscuits based on organic raw materials. Eureka: Life Sciences, 1, 59-64.

Tsuchiya, H. (2015). Membrane interactions of phytochemicals as their molecular mechanism applicable to the discovery of drug leads from plants. Molecules, 20, 18923-18966.

Zakłos-Szyda, M., Pawlik, N., Polka, D., Nowak, A., Koziołkiewicz, M., \& Podsędek, A. (2019). Viburnum opulus fruit phenolic compounds as cytoprotective agents able to decrease free fatty acids and glucose uptake by caco-2 cells settings. Antioxidants, 8(8), 262.

Zamorska, I. (2018). Polipshennia konstentratcii zamorozhenykh piurepodibnykh sumishey na osnovi piure sunychnogo [Improvement of the consistency of frozen pastelike mixtures based on strawberry]. Sauce Technical Sciences and Technologies, 11(1), 188-194 (in Ukrainian).

Živělová, I., \& Crhová, M. (2013). Organic food market in the Czech Republic. Acta Universitatis Agriculturae et Silviculturae Mendelianae Brunensis, 61(2), 539-546. 